\title{
The effect of ecological restoration based artificial reoxygenation on water quality Improvement of urban river water
}

\author{
Nan Luo ${ }^{1,2}$, Changying $\mathrm{Hu}^{2}$, Weiyu $\mathrm{Li}^{2}$, Tao Xie ${ }^{2,3}$, HuiLi Gong ${ }^{1 *}$ and Rui $\mathrm{Liu}^{2 *}$ \\ ${ }^{1}$ College of Resource Environment and Tourism, Capital Normal University, Beijing, 100037, China; \\ ${ }^{2}$ China Sciences MapUniverse Technology Co., Ltd (MAPUNI), Beijing, 100101, China \\ ${ }^{3}$ Beijing Zhongkeyuqing Environmental Protection Technology Co., Ltd, Beijing, 100101, China
}

\begin{abstract}
Urban river pollution sources such as Combined Sewer Overflows (CSOs) or Illegally Discharging of Industrial Waste (IDIW) are generally hard to control on-site and cause serious water quality degradation problems across the nation. Therefore developing effective in-situ remediation techniques for urban rivers is of great interest. In this research we combined river reoxygenation, artificial floating island and microbial agents technologies (OAFI-MA) to developed a comprehensive in-situ remediation technique and obtained water quality data from Sunhe River case study to evaluate its effectiveness. Our discovery indicates that the O-AFI-MA technique effectively improves water quality by reducing chemical oxygen demand $\left(\mathrm{COD}_{\mathrm{Cr}}\right)$, total phosphorous $(\mathrm{TP})$, ammonium nitrogen $\left(\mathrm{NH}_{4}{ }^{+}-\mathrm{N}\right)$ level by $45.9 \%, 61.31,7.66 \%$ respectively and our technique enhances the natural degradation rate by raising the dissolved oxygen (DO) level from $2.8 \mathrm{mg} / \mathrm{L}$ to $10 \mathrm{mg} / \mathrm{L}$ upstream. The case study suggests that the sediment accumulation from CSOs and the subsequent internal source release causes great water quality degradation for Sunhe River. We also tested combinatory microbial agents, physical adsorption and multimedia bio-filter bed technologies independently on site to improve the ammonium nitrogen and total phosphorous removal rate of our technique, and the multimedia bio-filter bed is found to be most effective.
\end{abstract}

\section{Introduction}

The treatment of Black and odorous water body has become an important part of improving urban living environment for local people. In order to quickly eliminate the black and odorous problems, traditional engineering methods such as sediment dredging, water diversion dilution, enhanced flocculation and other technologies are often used [1-5]. However the lack of complete sewage interception often renders the treatment process fruitless even with a great amount of manpower, resources and government funds invested. Sewage problems are prone to rebound after treatment and flooding increasingly becomes a threat [6-8]. The downside of "engineering water control" is becoming more severe in the new era.

Sunhe River is a typical Black-odor River Water Body located in Beijing. It is a beheaded stream with domestic sewage replacing its source. The water of Sunhe River appears black with violent odor emitting all the year round and the aquatic lifeforms in the river have all deceased, leaving the water untreated poses a threat to health condition of all people living in the vicinity of the river. In this study, Sunhe River was selected as the research subject for urban river ecological restoration. Through the comprehensive technology of artificial aeration [9], artificial floating island $[10,11]$ and microbial agents [12] (O-AFI-MA), the effect and influence of the O-AFI-MA on Black and odorous Water Body treatment were investigated.

\section{The general situation of Sunhe River}

Sunhe River is a tributary of Wenyu River that originates from the town of Sunhe at Chaoyang District, Beijing. The river connects Sunhe Community Health Center (upstream) with Beidian sewage treatment plant (downstream) from southwest to northeast along Jinmi Road. Sunhe river stream is converged with sewage collected from Kangying community at Beidian sewage treatment plant near the west side of Binhe Road and discharged into Wenyu River after being treated. The overall river course of Sunhe River is shown in Figure 1.

The source of the Sunhe River is the sewage originated from the sewage culvert under the bridge across the junction between Xidian Middle Street and Huangkang Road in the town of Sunhe. The volumetric flow rate is

*Corresponding author. Tel.: +886 01068901196; E-mail address: gonghl@263.net. 
about $4000-6000 \mathrm{~m}^{3} / \mathrm{d}$. The total length of the open channel of Sunhe River is about $2.3 \mathrm{~km}$, with a width ranging from $2.5 \mathrm{~m}$ to $4 \mathrm{~m}$, and water depth from about $20 \mathrm{~cm}$ to $40 \mathrm{~cm}$. For the middle reaches of Sunhe River, both side of riverbanks are covered with natural vegetation with only a few rain vents scattered along the river, and the point source pollution inflow here is less severe comparing to other parts of the river. For lower reaches of Sunhe River, under the bridge across Shun Huang Road, another stream of sewage dischargs directly into the river. The overall water quality of the river drastically exceeds the Environmental Quality Standards for Surface Water (BG3838/2002) issued by the government. Almost all parts of the river is contaminated by dense domestic sewage. This makes Sunhe River a typical black and odorous water body with milky white appearance and pungent odor.

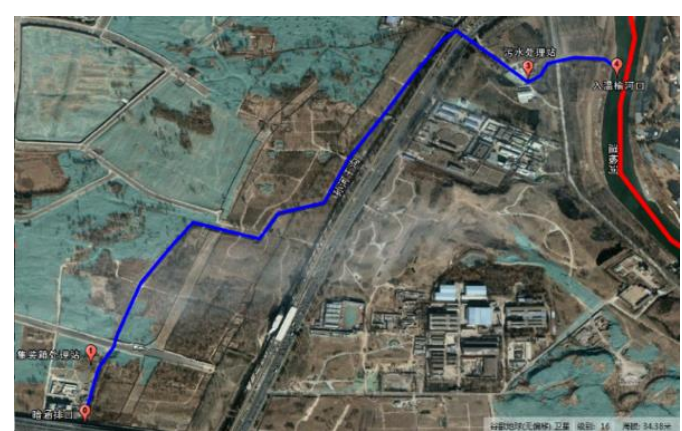

Figure 1. Satellite image of the Sunhe River

Most of the effluent from the upper-reaches sewage culvert is pumped to an ex-situ package sewage treatment plant on the nearby river bank and discharged back into the main channel of the Sunhe River. Detailed water quality of untreated water and treated water are shown in Table 1. Photography of both sections are shown in Figure 2.

Table 1. Raw water quality of Sunhe River

\begin{tabular}{cccccc}
\hline NO. & Sampling location & $\mathbf{C O D}(\mathbf{m g} / \mathbf{L})$ & $\mathbf{N H}_{\mathbf{4}^{+}-\mathbf{N}(\mathbf{m g} / \mathbf{L})}$ & $\mathbf{T P}(\mathbf{m g} / \mathbf{L})$ & $\mathbf{D O}(\mathbf{m g} / \mathbf{L})$ \\
\hline 1 & $\quad \begin{array}{c}\text { Upper reaches sewage } \\
\text { culvert }\end{array}$ & 104.02 & 13.99 & 1.32 & 0.69 \\
2 & $\begin{array}{c}\text { Package sewage treatment } \\
\text { plant outlet }\end{array}$ & 97.71 & 12.51 & 0.42 & 0.65 \\
\hline
\end{tabular}

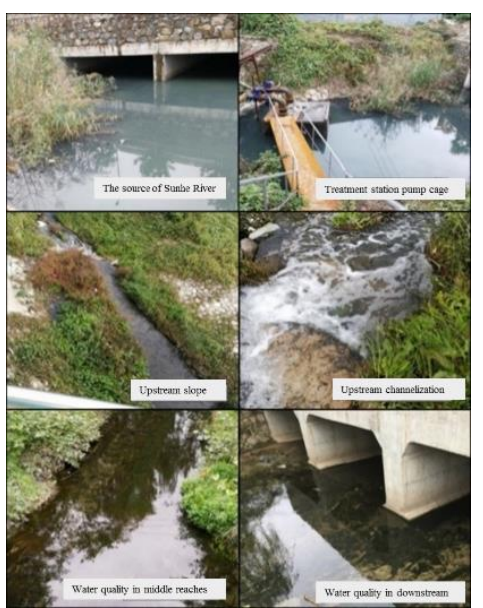

Figure 2. Photograph along the Sunhe River

\section{Experimental materials and methods}

\subsection{Construction plan of Sunhe River Ecological Restoration Project}

\subsubsection{Overall design of Sunhe River Ecological Restoration Project}

The project focuses on improving the water quality of over a 1849 meters length of the river between the flocculation package treatment plant (Point $0+078$ ) to the bridge across Shunhuang Road (Point 1+927), and ultimately improve water quality of the Wenyu River.

For this project a water treatment station was set at Point $0+078$ (50m north from the flocculation package treatment plant) based on the overall water quality, pollution-load and reoxygenation equipment's processing capacity. The treatment station is equipped with a set of reoxygenation equipment that is capable of processing over $2400 \mathrm{~m}^{3}$ of sewage water per day by utilizing oxygen (93\% pure) generated on-site. A supplementary cofferdam was also built between point $0+078$ and $0+300$ to form the water distribution area with an average depth of $1.4 \mathrm{~m}$. The water distribution area was designed with a retention time of around 2 hours to provide sufficient time for O-AFIMA treatment process to take effect.

Between points $0+300$ to $0+781$, a 500 meters long artificial floating island (AFI) reaction zone was to be set up, and a subsequent combinatory microbial agents were "seeded" at point $0+300$. The seeding process rapidly set up water-purifying microbiome beneath AFIs by embedding carbon fiber-biofilm-media with selectively cultured bacteria. The layout of the project design is shown in Figure 3.

To set up the correct microbiome for water purification, the water treatment station was installed and operated for one full month to revert the original anaerobic environment via reoxygenation. This reversion was followed by the introducing of AFIs that are packed with fresh carbon nanofiber contact media to grow both anaerobic and aerobic bio-film. To further enhance the purification capabilities of AFIs, several dosage of electively cultured microbial agents were added one week 
after the AFIs were installed.

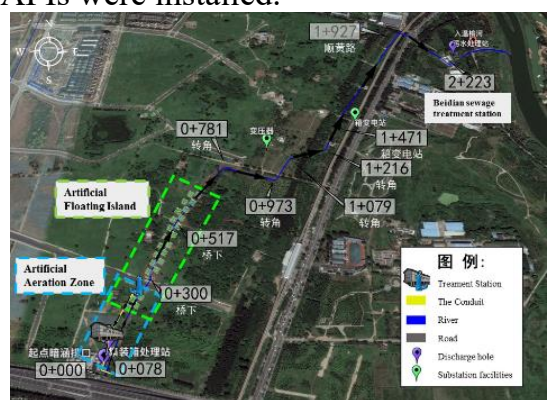

Figure 3. Schematic map of Sunhe River Demonstration Project

\subsubsection{Restoration technique}

This project adopts the O-AFI-MA technology provided by Beijing Zhongkeyuqing Environmental Protection Technology Co., Ltd. The main components of O-AFIMA includes artificial reoxygenation equipment, carbonnanofiber artificial floating island, and microbial agents (as shown in Figure 4). A national patent was also granted for O-AFI-MA technique (patent: ZL201620509104.X).

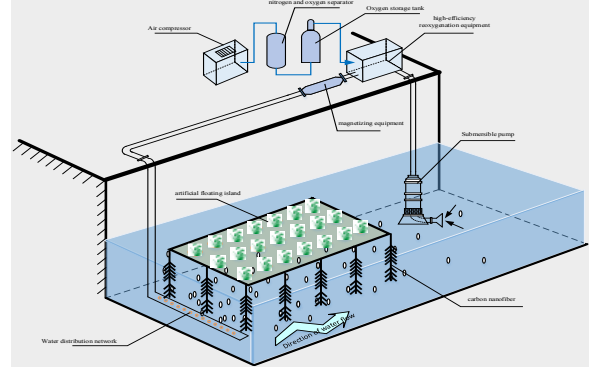

Figure 4. Schematic diagram of the O-AFI-MA technique

\subsubsection{Artificial reoxygenation technology (O)}

In this project, the high-efficiency reoxygenation equipment (model: ZKYQ-100) is used as the artificial reoxygenation equipment. A set of submersible pumps are used to transfer water from downstream of the river to high-efficiency reoxygenation equipment and evenly diffused into upstream of the river after being treated with a perforated piping apparatus. The high-efficiency reoxygenation equipment was designed with capability of injecting $20 \sim 30 \mathrm{mg} / \mathrm{L}$ dissolved oxygen for every cubic meter water treated. This is achieved by adopting $93 \%$ pure oxygen source (PSA generator) in combining with an oxygen-water mixing chamber specifically designed to break down bulky water cluster at molecular level. The schematic design is shown in Figure 5.

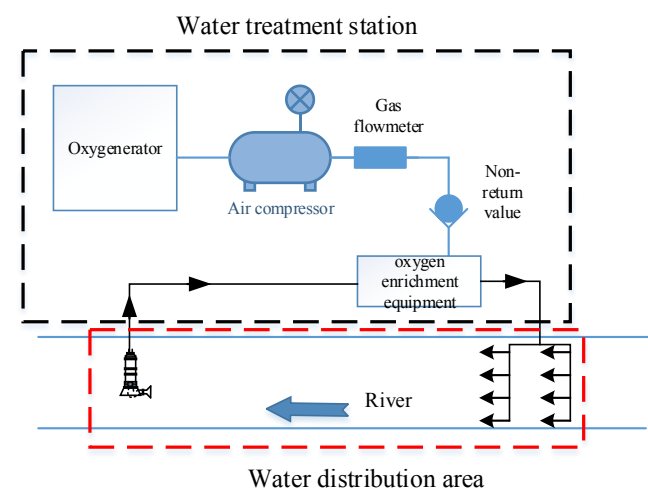

Figure 5. Schematic design of O-AFI-MA

\subsubsection{Carbon nanofiber AFIs}

A $500 \mathrm{~m}$ long carbon nanofiber artificial floating island arrays were installed downstream of the artificial reoxygenation equipment. Since the impact of storm water discharged during summer might cause major damage, AFIs are equipped with high density PVC floating frames anchored by stainless steel wires. The length of carbon nanofiber bio-film media was carefully measured to avoid rapture damage caused by dragging (Figure 6). The carbon nanofiber used in this project was developed by the Water Treatment Engineering Center of Beijing University of Chemical Technology as high-performance bio film growth media [13]. Mechanical and biological properties of carbon nanofiber are shown in Table 2.

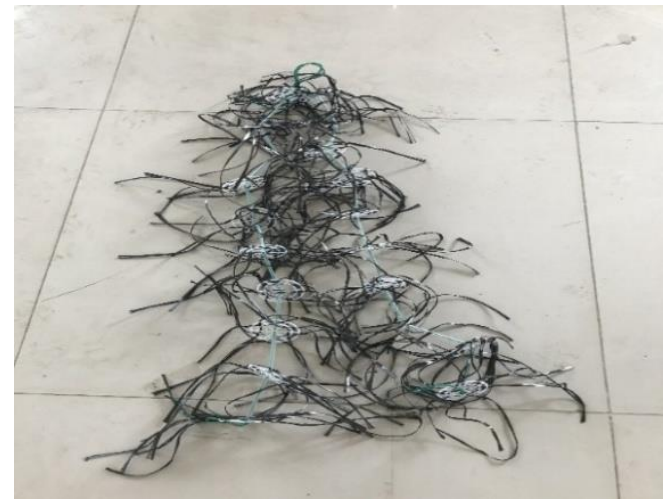

Figure 6. Photograph of carbon nanofiber

Table 2. Performance parameters of carbon-nanofibers

\begin{tabular}{cccccccc}
$\begin{array}{c}\text { Tensile } \\
\text { strength } \\
(\mathbf{G P a})\end{array}$ & $\begin{array}{c}\text { Tensile } \\
\text { modulus } \\
(\mathbf{G P a})\end{array}$ & $\begin{array}{c}\text { Elongatio } \\
\mathbf{n} \text { at break } \\
(\%)\end{array}$ & $\begin{array}{c}\text { Diameter } \\
(\boldsymbol{\mu} \mathbf{m})\end{array}$ & $\begin{array}{c}\text { Body density } \\
\left(\mathbf{g} / \mathbf{c m}^{3}\right)\end{array}$ & $\begin{array}{c}\text { Line density } \\
(\mathbf{g} / \mathbf{K m})\end{array}$ & $\begin{array}{c}\text { Carbon } \\
\text { content } \\
(\%)\end{array}$ & $\begin{array}{c}\text { Specific surface } \\
\mathbf{a r e a}^{(\mathbf{m})}\left(\mathbf{m}^{2} / \mathbf{m}^{3}\right)\end{array}$ \\
\hline 4.92 & 240 & 2.1 & 7 & 1.80 & 880 & 93.2 & 54000 \\
\hline
\end{tabular}

\subsubsection{Microbial agents (MA)}

The microbial agents were used to reconstruct the river microbiome for the purposes of nitrification, phosphate removal and general water purification. This purpose is achieved by immobilizing microorganisms via thick layer 
of biofilm on surface of carbon nanofiber. The microbial agents used in the project are BZT type nitrification, water purification as well as Biqing microbial agents provided by Shandong Bio-form Co., Ltd.

\subsection{Mechanism study}

To achieve ammonium nitrogen removal goal of this project, a pilot study was carried out before the project study and a water purification mechanism was purposed based on experimental facts. The pilot study includes several aspects which are the effect of endogenous release from river sediment on the water quality of Sunhe River, the effect of different microbial agent dosage on the improvement of river water quality, and compared several methods to efficiently remove ammonium nitrogen from Sunhe River.

\subsubsection{Experiment effect of river protists and sediments on Sunhe water quality}

The Sediment Releasing Experiment is conducted under a semi-enclosed environment where only compressed air is introduced to avoid eternal-source microbe contamination. Two 18-liter plastic buckets were used to extract $15 \mathrm{~L}$ of water near the submerged pump within reoxygenation reaction zone. $2 \mathrm{~L}$ of river sediment was added only to the second bucket. Both buckets were stored under shade near the river to maintain a steady temperature (as shown in Figure 7). The dissolved oxygen concentration was kept above $5 \mathrm{mg} / \mathrm{L}$ by air-diffuser aeration without disrupting the sediments added to simulate a dissolved oxygen concentration that is similar to what was found in oxygenated Sunhe River. We sample each sites first at 5:00 and then at around 15:00 during summer season on daily basis to study the effect of temperature variation. We evaluate each sample's CODCr, NH4+-N, TP by employing the National standard techniques. Based on evaluation results, we examine samples microscopically for Protozoa and microbial activities and conduct correlated Sediment Releasing Capacity Experiments to detect endogenous pollution.

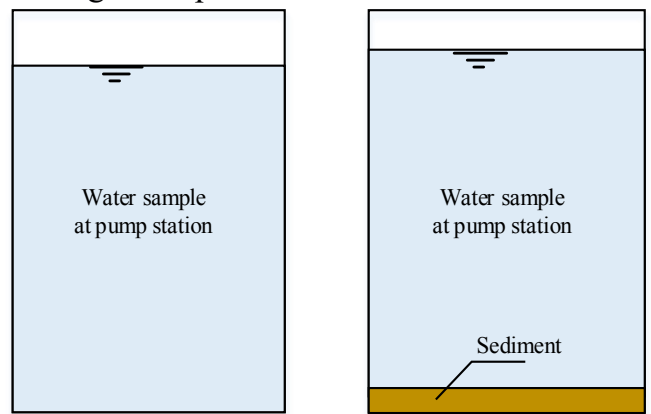

Figure 7. Schematic diagram of river water and sediment test

\subsubsection{Pilot study of $\mathrm{NH}_{4}{ }^{+}-\mathrm{N}$ removal in Sunhe River}

\subsubsection{Nitrification microbial agents}

About $15 \mathrm{~L}$ of the river water is placed in a plastic bucket and an air-diffuser aeration apparatus was introduced to maintain a 5-9mg/L dissolved oxygen level. Nitrobacteria and ammonia nitrogen agents (BZT type) are added to the bucket in batches. We collect water samples every day to test each sample's $\mathrm{COD}_{\mathrm{Cr}}, \mathrm{NH}_{4}{ }^{+} \mathrm{N}$ and TP. The experimental design of $\mathrm{NH} 4+-\mathrm{N}$ removal study is shown in Table 3.

Table 3. Microbial inoculum for removal of ammonia nitrogen addition method

\begin{tabular}{cccc}
\hline Time & $\begin{array}{c}\text { Nitrifying } \\
\text { bacteria } \\
\text { (gram) }\end{array}$ & $\begin{array}{c}\text { Ammonia } \\
\text { nitrogen } \\
\text { bacteria } \\
\text { (gram })\end{array}$ & $\begin{array}{c}\text { Sampling } \\
\text { time }\end{array}$ \\
\hline Day 1 & 2.5 & 2.5 & $15: 30$ \\
Day 2 & 2.5 & 2.5 & $15: 30$ \\
Day 3 & 0 & 0 & $15: 00$ \\
Day 4 & 1 & 1 & $15: 00$ \\
Day 5 & 0 & 0 & $15: 30$ \\
Day 6 & 0 & 0 & $15: 30$ \\
Day 7 & 0 & 0 & $15: 00$ \\
\hline
\end{tabular}

\subsubsection{2 $\mathrm{NH}_{4}{ }^{+}-\mathrm{N}$ absorption experiment}

Clinoptilolite, Montmorillonite, pearl dust and activated carbon were selected as ammonium-nitrogen adsorption materials [14]. The powder was weighed $2 \mathrm{~g}, 5 \mathrm{~g}$ and $10 \mathrm{~g}$ and placed in a sterilized conical bottle. Then the powder was added into $250 \mathrm{~mL} \mathrm{NH}_{4} \mathrm{Cl}$ solution (conc. $30 \mathrm{mg} / \mathrm{L}$ ). The reaction mixture was evenly mixed by using an electric shaker setting up at $25^{\circ} \mathrm{C} 100 \mathrm{rpm}$. The supernatant was sampled every half an hour to detect any change of ammonium-nitrogen.

Ammonium iron-exchange affinity is directly evaluated by parallel absorption tests, where the absorbent capacity of Clinoptilolite, Montmorillonite, pearl dust, activated carbon, etc. as ammonium $\left(\mathrm{NH}_{4}{ }^{+}-\mathrm{N}\right)$ absorbent are measured under standard experimental procedures. After an initial screening, testing candidates with promising capabilities are further tested under a progressively increasing ammonium concentration.

\subsubsection{Multi-media biological filter}

Based on the previous experimental results, the multimedia biological filter technology is selected to achieve intended $\mathrm{NH}_{4}{ }^{+}-\mathrm{N}$ removal rate. Multimedia biofilter technology utilizes polyurethane (PU) carrier with microscopic porous embedded with selectively cultured microbial agents. When the PU carrier is suspended in water, microorganisms can rapidly exchange oxygen and other substances with the surrounding environment. This process effectively lowers the $\mathrm{COD}_{\mathrm{Cr}}, \mathrm{NH}_{4}{ }^{+}-\mathrm{N}$ and TP concentration of water surrounding the PU carrier. This can achieved by a combination effect of organic media adsorption, microbial oxidation, fixation and biological extraction. The effluent with different hydraulic retention time (HRT) and aeration time was collected and tested. The water quality and DOM characterization data were obtained to determine $\mathrm{NH}_{4}{ }^{+}-\mathrm{N}$ removal rate. Schematic design of multi-media biological filter is shown in Figure 8 . 


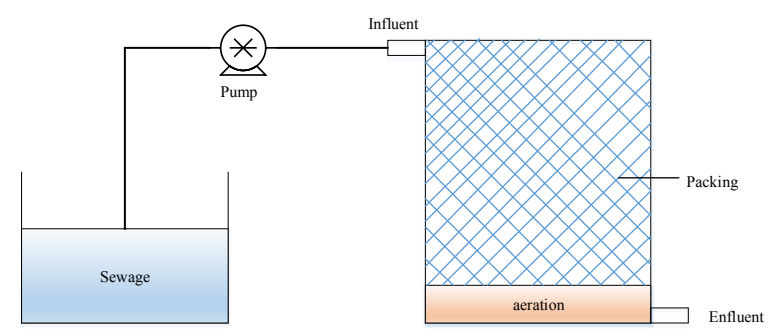

Figure 8. Schematic diagram of multi-media biological filter

\subsection{Testing instruments}

The testing instruments and methods used in this experiment for water quality analysis are shown in the Table

Table 4. Methods and instruments for water quality analysis

\begin{tabular}{|c|c|c|c|}
\hline index & Methods & Instrumentation & $\begin{array}{l}\text { manufacture } \\
\mathbf{r}\end{array}$ \\
\hline $\mathrm{NH}_{4}{ }^{+}-\mathrm{N}$ & $\begin{array}{l}\text { Nessler's } \\
\text { reagent } \\
\text { spectroph } \\
\text { otometry }\end{array}$ & $\begin{array}{c}\text { Lianhua 5B-3 (B) } \\
\text { multiple speed } \\
\text { measuring } \\
\text { instrument }\end{array}$ & Lianhua \\
\hline COD & $\begin{array}{l}\text { Potassium } \\
\text { dichromat } \\
\text { e method }\end{array}$ & $\begin{array}{c}\text { Lianhua 5B-3 (B) } \\
\text { multiple speed } \\
\text { measuring } \\
\text { instrument }\end{array}$ & Lianhua \\
\hline TP & $\begin{array}{l}\text { Molybden } \\
\text { um } \\
\text { antimony } \\
\text { photometr } \\
\text { ic method }\end{array}$ & $\begin{array}{c}\text { Lianhua 5B-3 (B) } \\
\text { multiple speed } \\
\text { measuring } \\
\text { instrument }\end{array}$ & Lianhua \\
\hline $\begin{array}{l}\text { Microor } \\
\text { ganism }\end{array}$ & & $\begin{array}{c}\text { BD-SW4001 } \\
\text { biomicroscope }\end{array}$ & Boschda \\
\hline DO & $\begin{array}{c}\text { Spectroph } \\
\text { otometric } \\
\text { method }\end{array}$ & $\begin{array}{c}\text { AZ8403 portable } \\
\text { dissolved oxygen } \\
\text { instrument }\end{array}$ & $\mathrm{AZ}$ \\
\hline
\end{tabular}

\section{Results and discussion}

\subsection{Water Quality Improvement Results of Sunhe River Ecological Restoration Project}

The ecological restoration project was first started on January 17, 2018. After two months of trial operation on March 15, 2018, it was officially put into operation. After more than six months of ecosystem reconstruction, the water quality of Sunhe River has been significantly improved. A significant improvement of water quality was observed. The transparency was increased from $10 \mathrm{~cm}$ to an average of $60 \mathrm{~cm}$ and peaking at $80 \mathrm{~cm}$, and the growth of benthic plants were observed. Water quality data of samples collected form upper to lower reaches of Sunhe River shows a solid removel of Organic, phosphoric and ammonic pollutant. The ecological restoration project effectively lowered $\mathrm{COD}_{\mathrm{Cr}}$ by an average of $45.9 \%$ over six months period. The average removal rate of TP over the last six months was $61.31 \%$, and the average removal rate of $\mathrm{NH}_{4}^{+}-\mathrm{N}$ over the last six months was $7.66 \%$ (as is shown in Figures 9 to 10).

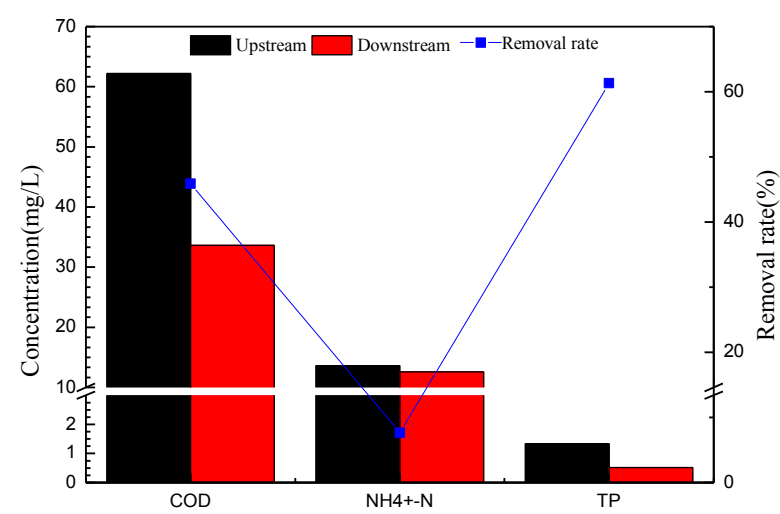

Figure 9. Average removal rate of $\mathrm{COD}_{\mathrm{Cr}}, \mathrm{NH}_{4}{ }^{+}-\mathrm{N}$ and $\mathrm{TP}$ of upstream and downstream Sunhe River over 6 months period
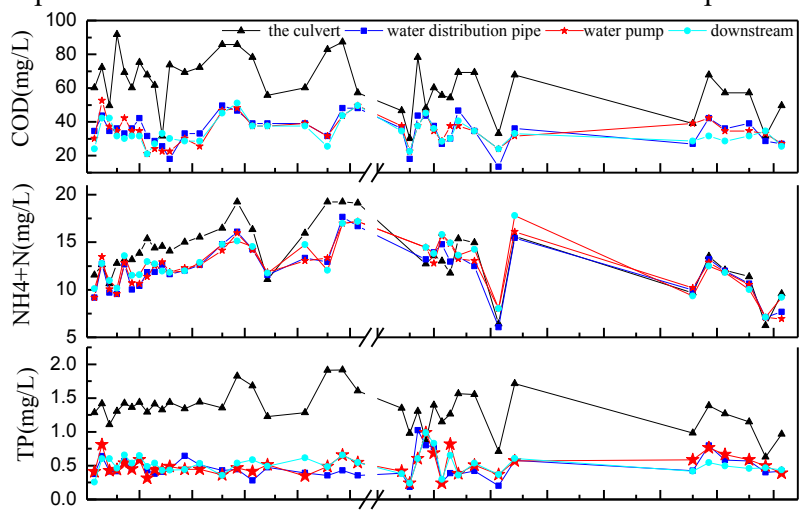

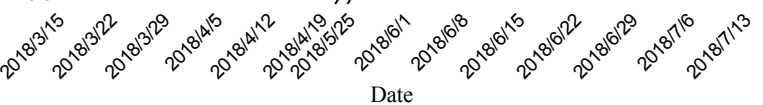

Figure 10. Detailed $\mathrm{COD}_{\mathrm{Cr}}, \mathrm{NH}_{4}{ }^{+}-\mathrm{N}$ and $\mathrm{TP}$ testing results for each different sampling points over 6 months period

We compared the average water quality data collected from upper reaches sewage culvert (the culvert), reoxygenation equipment diffusing pipe (water distribution pipe), submerged pump (water pump) and downstream of cofferdam for over six months. The results clearly showed that reoxygenation equipment has effectively raised dissolved oxygen level. The dissolved oxygen concentration of the culvert raise from $2.8 \mathrm{mg} / \mathrm{L}$ to $10 \mathrm{mg} / \mathrm{L}$, and the dissolved oxygen for $2 \mathrm{~km}$ downstream is stabilized at about $4 \mathrm{mg} / \mathrm{L}$ (as is shown in Figure 11).

Because the water quality of distribution pipe is of minor difference compare to that of flocculation package treatment plant effluent, the water sample at the distribution pipe is treated as if it was taken form flocculation package treatment plant outlet to simplify the experimental process. From the figure 12, it can be seen that the flocculation-sedimentation process contributed the most to TP removal, with an average rate of $68.5 \%$. Flocculation-sedimentation process has limited effect on $\mathrm{COD}_{\mathrm{Cr}}$ and $\mathrm{NH}_{4}{ }^{+}-\mathrm{N}$ removal, with a removal rate of $6.05 \%$ and $11.64 \%$ respectively. It can also be seen from the trendline of diagram that TP and $\mathrm{NH}_{4}{ }^{+}-\mathrm{N}$ first rise than fall as we move from the water distribution pipe to the Sunhe River downstream. This result appeared intriguing since the middle reaches of Sunhe river is mostly surrounded by natural environment where little to none human activities including the drainage of rain and sewage can be found nearby. This result suggested a possibility that endogenous release form river sediment might be related 
to the fall and rise of $\mathrm{TP}$ and $\mathrm{NH}_{4}{ }^{+}-\mathrm{N}$ from upstream to downstream. Please refer to 4.2 to see the detailed analysis.

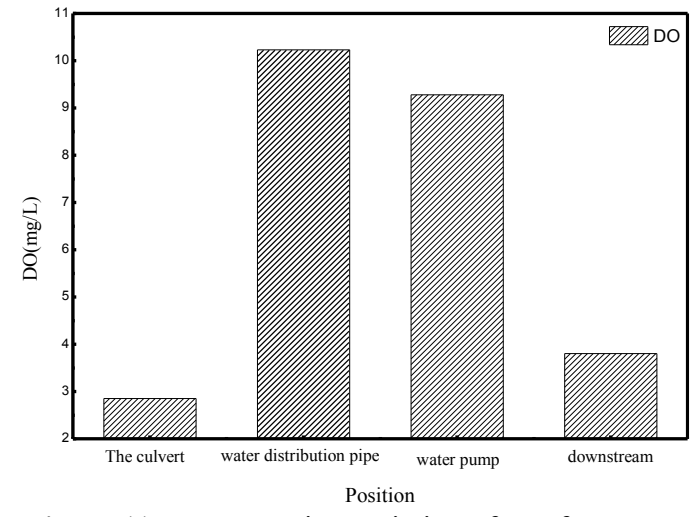

Figure 11. Concentration variation of DO from upstream to

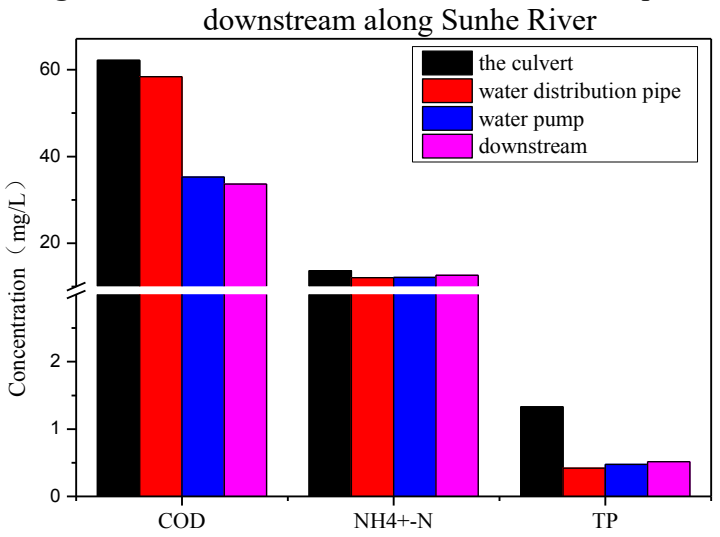

Figure 12. Concentration variation of $\mathrm{COD}_{\mathrm{Cr}}, \mathrm{NH}_{4}{ }^{+}-\mathrm{N}$ and TP from upstream to downstream along Sunhe River

The $\mathrm{COD}_{\mathrm{Cr}}$ removal rate for each individual process of O-AFIs-MA technique can be deducted using our experimental data. Flocculation-sedimentation process has limited effect on $\mathrm{COD}_{\mathrm{Cr}}$ reduction, which accounts for only $12 \%$ of the total decrease. The carbon nanofiber AFIs also has limited effect to $\mathrm{COD}_{\mathrm{Cr}}$ reduction, which accounts for $9 \%$ of the total decrease. The reoxygenation equipment contributed the most to the $\mathrm{COD}_{\mathrm{Cr}}$ reduction, which accounts for $79 \%$ of the total decrease. By excluding the effect of flocculation-sedimentation process the net reduction rate of Sunhe River ecological restoration process is equal to $88 \%$ of the total $\mathrm{COD}_{\mathrm{Cr}}$ reduction rate. Literature review of similar projects shows a 20 to $30 \%$ reduction for both $\mathrm{COD}_{\mathrm{Cr}}$ and $\mathrm{NH}_{4}{ }^{+}-\mathrm{N}$ [15] while our project data, in comparison, showed a much-lower $4.6 \%$ COD ${ }_{\mathrm{Cr}}$ removal rate and little to none $\mathrm{NH}_{4}{ }^{+}-\mathrm{N}$ removal. We observed that the effluent of flocculationsedimentation process contains considerable amount of flocs ( $\leq 5 \%$ in volume) because of inappropriate operation such as filter press failure. This leaking problem enabled high molecular weight PAC and PAM to form a dense coating over the natural sediments causing long-term detrimental effects to various aquatic lifeforms. This significantly limited the oxygen exchange between water and sediments therefore drastically decreases the population of benthic and water-born microorganisms in Sunhe River and with decreased microorganisms population the net weight of biofilm grew in carbon nanofiber AFIs was also decreased significantly. The viscosity of biofilm is very low and has an iconic black color. The results of microscopic examination of fibrous fillers can be seen (as shown in Figure 14) that the bacterial micelles are loosely packed with almost no filamentous bacteria present. Chlorella and nematodes in the bacterial micelles also indicates that the selfpurification capability under the effect of leaking flocs is significantly reduced. Such environment in river can lead to low microbial activity and decrease of self-purification capability for carbon fiber carriers [16].

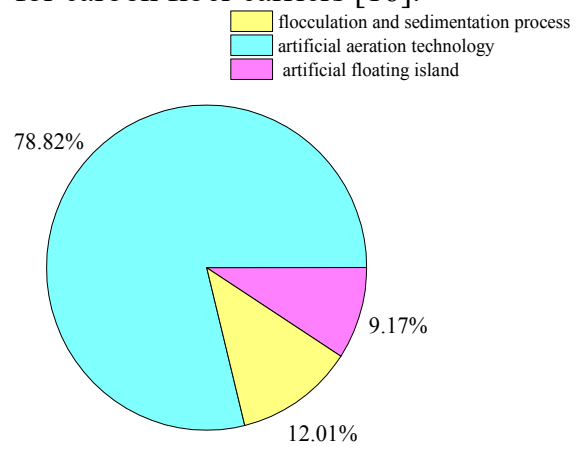

Figure 13. Different treatment process's contributions to total CODcr reduction

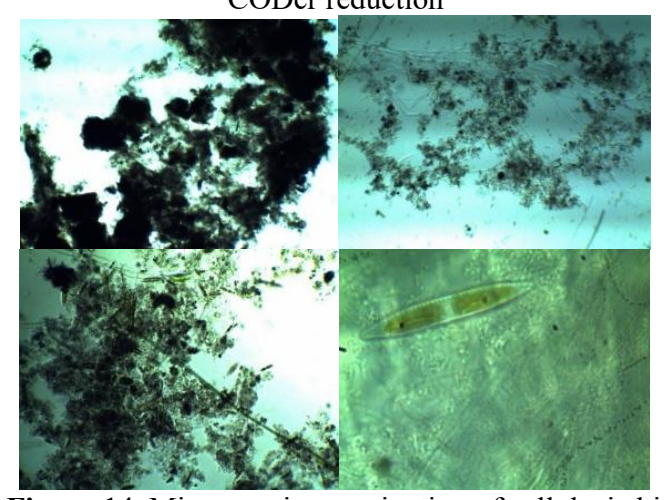

Figure 14. Microscopic examination of cellulosic biofilm micelles

\subsection{Effect of endogenous release of river sediment on water quality}

The static sediment release experiment suggested that the river sediment has a continuous endogenous releasing effect. As shown in Figure 15, the endogenous release of $\mathrm{COD}_{\mathrm{Cr}}, \mathrm{NH}_{4}{ }^{+}-\mathrm{N}$ and TP are severe over the first 58 hours. It can be seen from the diagram that after 106 hours of static intermittent aeration, $\mathrm{NH}_{4}^{+}-\mathrm{N}$ and $\mathrm{TP}$ in the raw water with no sediments added were reduced over time. The $\mathrm{COD}_{\mathrm{Cr}}$ level was slightly increased, but eventually stabilized. This result suggests that the ecological restoration project has successfully recovered the selfpurification capabilities of Sunhe River. The second experiment was conducted with sediments and the experimental result suggested that $\mathrm{COD}_{\mathrm{Cr}}, \mathrm{NH}_{4}{ }^{+}-\mathrm{N}$ and TP increased significantly in comparison to first experiment which involved little sediments. After 106 hours of experiment, the final $\mathrm{COD}_{\mathrm{Cr}}$ level reached $400 \%$ of the starting value. The final $\mathrm{NH}_{4}{ }^{+}-\mathrm{N}$ level also reached $230 \%$ of the starting value after the experiment with a net increase of $7.011 \mathrm{mg} / \mathrm{L}$. The final TP level reached $115 \%$ of the starting value after the experiment, with a net 
increase of $0.378 \mathrm{mg} / \mathrm{L}$.

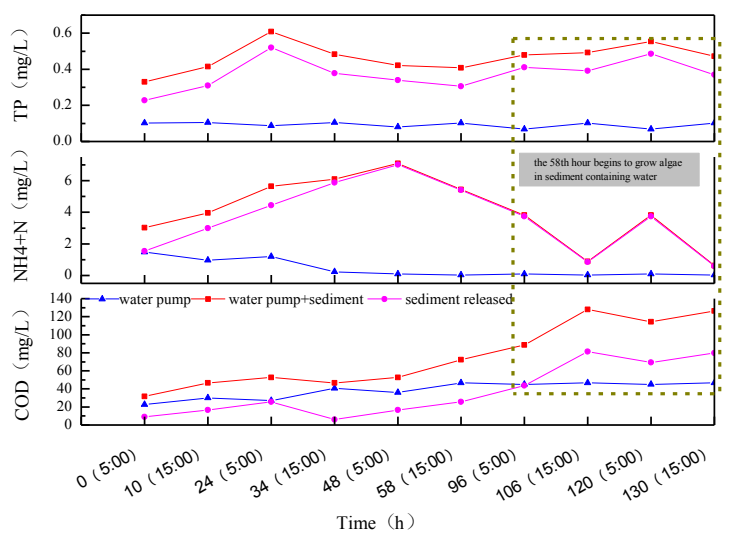

Figure 15. Results of endogenous release experiment

Significant traces of algae growth in all test samples can be discovered from the 58th on-going hour of of experiment where sediments were added. With this active algae growth-decay cycle observed. We reasoned that trace of Hormospores present in the tested sediment eventually caused that blue and green algae to thrive in an enclosed environment. In-situ studies also shows an increasing trend of algae colonies density peaking at 15:00 of a day and minimizing at 5:00 of a day. This trend is discovered by mapping the water quality trend line over a whole day period. We discovered that the total nitrogen and total phosphorous increases via hypoxia digestion in sediments shortly after algae decaying when the surroundings environment thermally plummets. However, the total nitrogen and total phosphorous decreases sharply when the surrounding is best suited for algae growth. This "rapid growth-and-decay cycle of algae", in addition to heavy endogenous releasing significantly deteriorates the water quality in such a way that releasing rate of pollutants eventually surpluses the degradation rate. This evidently makes the downstream pollutant concentrations stands above the upstream concentrations despite the fact that water was treated upstream with ex-situ remediation techniques followed by an in-situ remediation in the river [17].

\subsection{Discussion of different $\mathrm{NH}_{4}{ }^{+}-\mathrm{N}$ removal technologies for Sunhe River}

\subsection{1 $\mathrm{NH}_{4}^{+}-\mathrm{N}$ removal effect by Microbial inoculum}

A small-scale ammonium nitrogen removal test with microbial inoculum was conducted with a significant $\mathrm{NH}_{4}{ }^{+}-\mathrm{N}$ removal effect (Figure 16). However microbial inoculum agent only works on static water body. Under normal circumstances with flowing water, this method has a very limited effect. This is mainly due to the fact that microbial agents, after applying to river, requires long time to take effect. Microbial inoculum eventually becomes relevant after those microorganisms become the dominant species after competing with wild type. For carbon nanofiber carrier microbial inoculum gradually takes occupancy from the wild type.

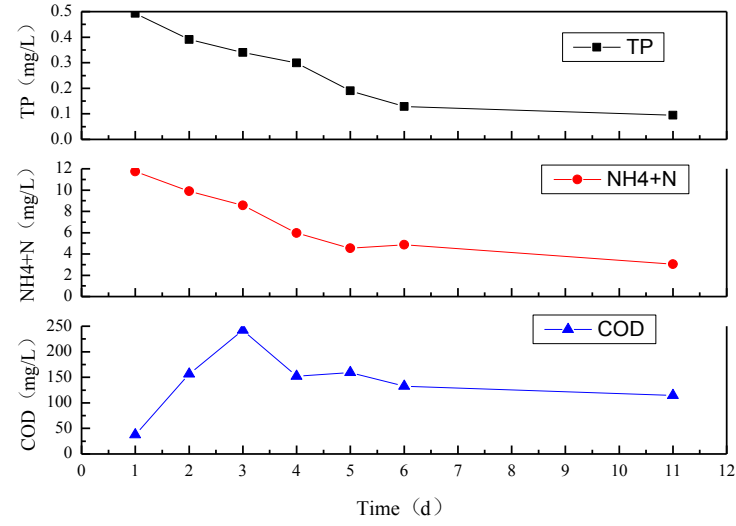

Figure 16. The time-variation of $\mathrm{NH}_{4}{ }^{+}-\mathrm{N}$ removal by adding microbial inoculum under the static condition

\subsection{2 $\mathrm{NH}^{+}-\mathrm{N}$ removal effect by adsorption}

As can be seen from Figure 17, Clinoptilolite has the best removal effect on $\mathrm{NH}_{4}^{+}-\mathrm{N}$, followed by montmorillonite, and pearl dust has the worst adsorption. The ammonia adsorption efficiency of these four materials increased with the increase of the dosage. The adsorption rate was the highest in the first 5 minutes of the reaction. The adsorption reached saturation after $1 \mathrm{~h}$, and the adsorption effect tended to be gentle. It can be concluded from Figure 18 that the removal rate of $\mathrm{NH}_{4}{ }^{+}-\mathrm{N}$ increases gradually with the increase of Clinoptilolite dosage. The removal rate of $\mathrm{NH}_{4}{ }^{+}-\mathrm{N}$ increases from $45 \%$ to $73 \%$ with the increase of Clinoptilolite dosage from $2 \mathrm{~g}$ to $10 \mathrm{~g}$.

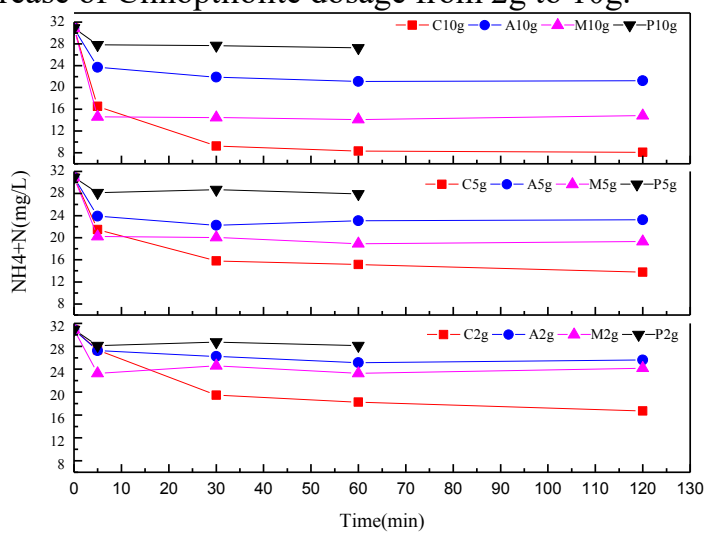

Figure 17. Time-variation of $\mathrm{NH} 4+\mathrm{N}$ concentration under different dosages of different adsorbents (Clinoptilolite as $\mathrm{P}$, Montmorillonite as M, Pearl dust as P and Activated carbon as A)

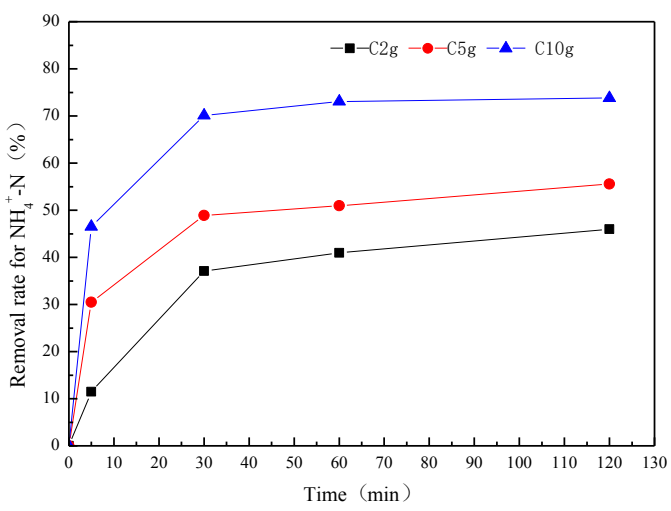

Figure 18. Effect of Clinoptilolite dosage on adsorption of NH4+-N 
It can be seen from Figure 19 that between the dosage of $0.5 \mathrm{~g}$ and $5 \mathrm{~g}$ Clinoptilolite used, the removal rate of $\mathrm{NH}_{4}{ }^{+}-\mathrm{N}$ increases significantly as the dosage increases. When the dosage is more than $5 \mathrm{~g}$, the removal rate of $\mathrm{NH}_{4}{ }^{+}-\mathrm{N}$ increases slowly as the dosage increases. The removal rate peaked at with $0.1 \mathrm{~g}$ of Clinoptilolite added but sharply decreased after it reaches its maximum capacity. The maximum adsorption capacity reached $0.164 \mathrm{mg} / \mathrm{g}$. When the dosage exceeded $1 \mathrm{~g}$, the adsorption capacity decreased sharply.
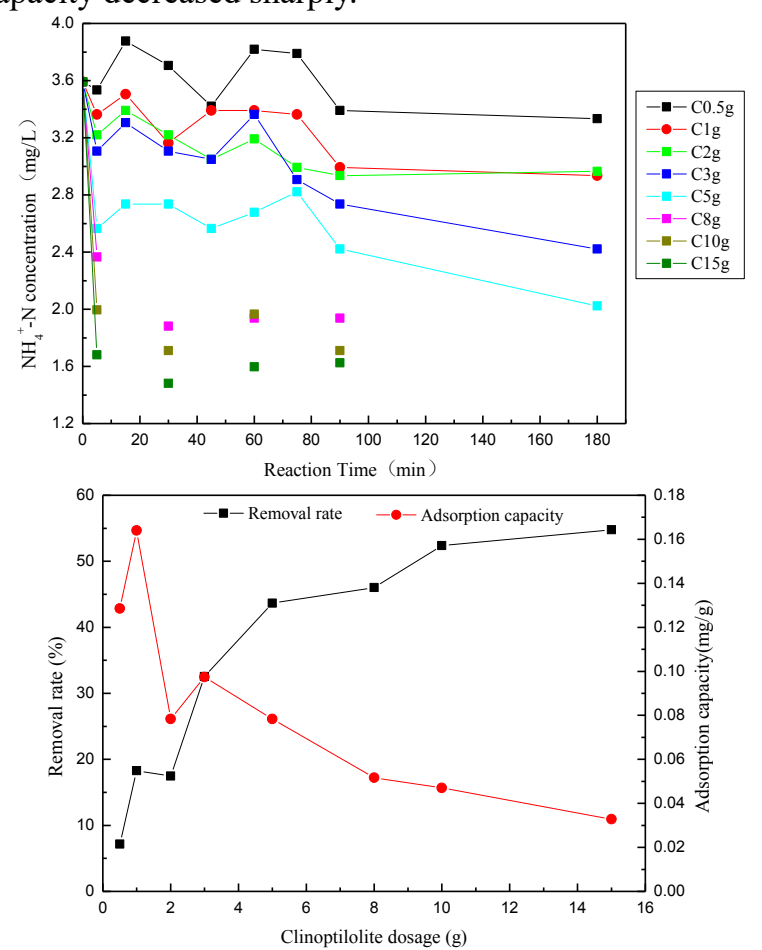

Figure 19. Effect of Clinoptilolite dosage on $\mathrm{NH}_{4}{ }^{+}-\mathrm{N}$ removal in Sunhe River

\subsection{3 $\mathrm{NH}_{4}{ }^{+}-\mathrm{N}$ removal by Multi-media Biological Filter}

Through the treatment of the raw water of Sunhe River, it is found that the removal efficiency of $\mathrm{TP}$ and $\mathrm{TN}$ by multi-media biological filter is remarkable (Figure 20). The removal rate of total phosphorus and total nitrogen can reach up to $80 \%, 56 \%$ respectively with only 2 hours of hydraulic retention time. The $\mathrm{NH}_{4}{ }^{+}-\mathrm{N}$ removal rate decreased at first but then raised, while the TN removal rate varied little over time. We reasoned that this trend is due to the high level of organic nitrogen presents in domestic sewage that contaminated Sunhe River and automatically generates ammonium nitrogen after being digested by microorganisms. Ammonium nitrogen underwent nitrification nitrate nitrogen to produce nitric salt. At beginning of the experiment the conversion rate between organic ammonia to ammonium nitrogen is greater than the nitrification rate as the concentration of $\mathrm{NH}_{4}{ }^{+}-\mathrm{N}$ in the water will increase. This is likely caused by cellular uptake of ammonium nitrogen during bacteria growth period. However after the bacteria population become steady this conversion rate will decrease, which causes the rises and fall of $\mathrm{NH}_{4}^{+}-\mathrm{N}$. This is another reason why $\mathrm{NH}_{4}{ }^{+}-\mathrm{N}$ form downstream Sunhe river is higher than upstream.
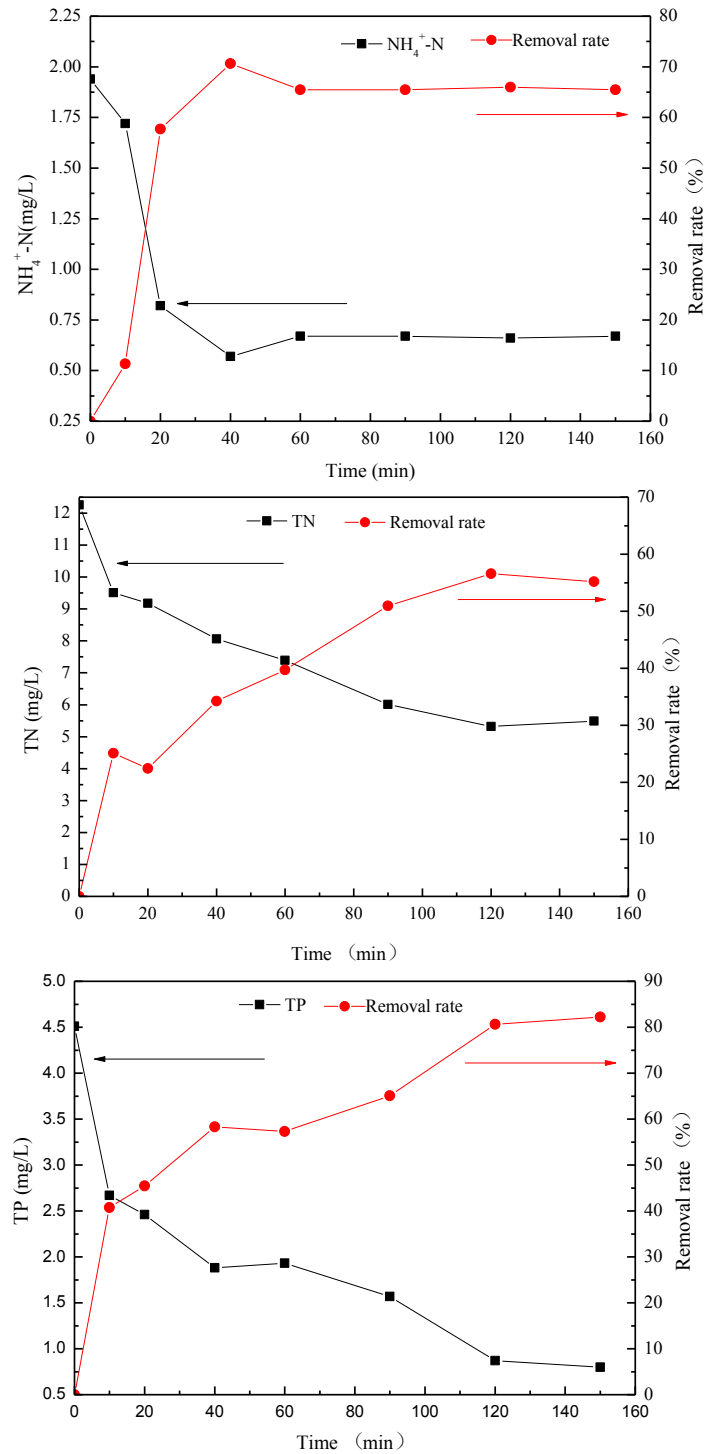

Figure 20. Time-variation of $\mathrm{NH}_{4}^{+}-\mathrm{N}, \mathrm{TN}$ and TP of Sunhe raw water treated by Multi-media biological filter

\section{Conclusion and Prospect}

For the typical urban river with continuous sewage discharge, the O-AFI-MA has obvious effect on the improvement of water quality. The dissolved oxygen concentration of the culvert rises from $2.8 \mathrm{mg} / \mathrm{L}$ to 10 $\mathrm{mg} / \mathrm{L}$, and the dissolved oxygen $2 \mathrm{~km}$ downstream can be maintained at about $4 \mathrm{mg} / \mathrm{L}$. The water transparency also increased significantly from less than $25 \mathrm{~cm}$ to up to $80 \mathrm{~cm}$. The ex-situ flocculation-sedimentation process is a effective way to reduce TP level with a average removal rate of $68.5 \%$, but the effect of COD reduction is limited. The O-AFI-MA technique is effective for $\mathrm{COD}_{\mathrm{Cr}}$ reduction. Both of the these two technology has not significant effect on $\mathrm{NH}_{4}{ }^{+}-\mathrm{N}$ removal. Through the comparison of microbial agents, physical adsorption and multi-media biological filter, we found that multi-media biofilter bed is the most suitable technology for nitrogen and phosphorus removal.

Base on the results above we concluded that O-AFIMA technique coupled with ex-situ multi-media biological filter technology is an effective measure to 
improve the river water quality under low pollution load. This combined technology provides a novel way to improve water quality before a complete sewage interception can be achieved.

\section{Acknowledgment}

Foundation: Beijing Postdoctoral Research Foundation

\section{References}

1. G. Zhou, Water \& Wastewater Engineering, 6, 56-58 (2016).

2. L. Zhang, H. Wang, G. Li and Y. Xiong, Environmental Protection, 5, 62-65 (2017).

3. Y. Zhao, R. Yao, M. Xu and L. Song, Environmental Protection, 13, 27-29 (2015).

4. M. Xu, R. Yao, L. Song, Y. Wu, Y. Xie and D. Wang, Chinese Journal of Environmental Management, 2, 74-78(2015).

5. W. Liao, J. Huang, J. Ding, M. Liu, T. Chen, Q. Tong, Y. Yao and S. Lv, 2017 the ninth Forum on river lake management and water ecological civilization development, Xi'an, Shanxi province, China, 8(2017).

6. H. Hu, Y. Sun, J. Xi and T. Zhao, Environmental Protection, 13, 24-26(2015).
7. S. Wang, T. Zhang, Y. Gao, F. Zhao and P. Zhuang, Resources and Environment in the Yangtze Basin, 1, 215-224(2018).

8. S. Chang, Green Environmental Protection Building Materials, 2, 74(2018).

9. Z. Hu, C. Liu, Q. Zhou, C. Wu, W. Tu and Y. Liang, Chinese Journal of Environmental Engineering, 12, 4281-4288(2012).

10. P. Yeh, and Y. Chang, Renewable and Sustainable Energy Reviews, 47, 616-622(2015).

11. Y. Chang, C. Ku, and N. Yeh, ECOL ENG, 69, 816(2014).

12. J. Guo, W. Chen, F. Ma, L. Wei and L. Zhao, China Water \& Wastewater, 15, 76-80(2013).

13. L. Yang, R. Hai, M. Li, Y. Li and X. Wang, Environmental Science \& Technology, 11, 136141(2013).

14. H. Li, Hebei University of Engineering, 65(2018).

15. F. Zhao, S. Xi, X. Yang, W. Yang, J. Li, B. Gu, and Z. He, ECOL ENG, 40, 53-60(2012).

16. H. Fu, Environmental Protection \& Circular Economy, 8, 62-63(2013).

17. L. Cai, G. Zhu, J. Liu, S. Xiang, J. Liu, B. Chang, X. Dai and Y. Guo , China Environmental Science, 8, 3087-3093(2018). 